\title{
STRUKTUR HISTOLOGI TRAKEA TIKUS PUTIH (Rattus sp.) YANG TERPAPAR ASAP ROKOK SETELAH DIBERI EKSTRAK BUAH JUWET (Syzygium cumini L.)
}

\section{TRACHEAL HISTOLOGICAL STRUCTURE OF WHITE RAT (rattus SP.) WHICH EXPOSED TO CIGARETTES AFTER JAVA PLUM FRUIT (Syzygium cumini L.) EXTRACT TREATMENT}

\author{
I Komang Angga Kristiawan*, Ni Made Rai Suarni dan Dwi Ariani Yulihastuti \\ Program Studi Biologi, \\ Fakultas Matematika dan Ilmu Pengetahuan Alam, \\ Universitas Udayana Bukit Jimbaran, Bali \\ Email : anggakristiawan1992@gmail.com
}

\section{INTISARI}

Penelitian ini bertujuan untuk mengetahui pengaruh pemberian ekstrak buah juwet (Syzygium cumini L.) terhadap struktur histologi trakea tikus putih (Rattus sp) yang terpapar asap rokok. Penelitian ini menggunakan Rancangan Acak Lengkap (RAL) dengan 4 perlakuan yaitu kontrol $\left(\mathrm{K}_{0}\right)$ diberi larutan CMC-Na 0,5\%, kelompok $\left(\mathrm{K}_{1}\right)$ diberi paparan asap rokok, $\left(\mathrm{K}_{2}\right)$ diberi ekstrak buah juwet, $\left(\mathrm{K}_{3}\right)$ diberi paparan asap rokok dan ekstrak buah juwet dengan 6 kali ulangan. Paparan asap rokok diberikan sebanyak 1 batang rokok kretek yang dinyalakan dengan bantuan Aerator pump. Ekstrak buah juwet dan CMC-Na 0,5\% diberikan secara oral (metode gavage) selama 48 hari. Keberadaan silia diamati secara diskriptif komperatif. Sedangkan jumlah sel goblet, tinggi epitel, dan diameter lumen dianalisa dengan uji ANOVA dan bila berbeda nyata 5\% dilanjutkan dengan uji Duncan. Hasil menunjukkan bahwa pemberian ekstrak buah juwet secara nyata mampu memperbaiki struktur histologi trakea tikus yang telah terpapar asap rokok $(\mathrm{P}<0,05)$.

\section{Kata kunci : histologi trakea, radikal bebas, antioksidan, Rattus sp, Syzygium cumini L.}

\section{ABSTRACT}

This study aimed to determine the effect of juwet fruit extract on histological structure of rat(Rattus sp) trachea which exposed to cigarette smoke. This research used Completely Randomized Design (CRD), with four treatments: the control group $\left(\mathrm{K}_{0}\right)$ treated with $0.5 \% \mathrm{CMC}-\mathrm{Na},\left(\mathrm{K}_{1}\right)$ group is exposed to cigarette smoke, $\left(\mathrm{K}_{2}\right)$ group were given juwetfruit extract, and $\left(\mathrm{K}_{3}\right)$ group is exposed to cigarette smoke and juwet fruit extracts. Each treatment consisted of 6 rats as replication. The exposure to cigarette smoke is given from an aerator pump lit cigarettes. Juwet fruit extract and $0.5 \% \mathrm{CMC}-\mathrm{Na}$ was orally administered (gavage method) for 48 days. The existence of comperative descriptive observed cilia. And goblet number, high epithelium and lumen diameter Data were analyzed with ANOVA and If they were $5 \%$ significantly different would be followed by Duncan test. Results showed that the extract of the fruit juwet significant effect on the histological structure of the trachea mice that had been exposed to smoke.

\section{Keywords: histology trachea, free radicals, antioxidants, Rattus sp, Syzygium cumini L.}

\section{PENDAHULUAN}

Radikal bebas merupakan atom atau gugus atom yang memiliki satu atau lebih elektron tak berpasangan (Fajri dkk, 2015). Radikal bebas yang berada di dalam tubuh manusia berasal dari 2 sumber yaitu eksogen (berasal dari luar tubuh) dan endogen (berasal dari dalam tubuh). Salah satu contoh sumber radikal bebas eksogen adalah asap rokok (Muchtadi, 2013). Radikal bebas pada asap rokok dapat menimbulkan gangguan kesehatan seperti gangguan pada organ pernapasan (Susanna dkk, 2003). Kelainan yang ditimbulkan pada sistem pernapasan oleh paparan asap rokok dalam jangka waktu panjang diantaranya adalah berkurangnya jumlah silia pada epitel pseudokompleks bersilia (Samantha, et al., 2010). Perubahan struktur histologi yang terjadi pada trakea seperti bertambahnya sel goblet dan perubahan tinggi sel epitel pseudokomplek (Arkeman dan David, 2006).

Antioksidan mempunyai peran penting dalam menjaga keseimbangan jumlah radikal bebas didalam tubuh dengan cara menerima atau mendonorkan salah satu elekton pada radikal bebas (Sukmaningsih, 2015). Buah juwet berperan dalam menurunkan kadar glukosa darah (hipoglikemik), serta berperan dalam menekan produksi radikal bebas yang secara berlebihan terdapat dalam tubuh (Arifin dkk, 2006). Penggunaan ekstrak buah juwet belum pernah diteliti terhadap kemampuannya dalam menangani dampak buruk dari paparan asap rokok. Oleh karena itu, perlu dilakukan penelitian mengenai pengaruh ekstrak buah juwet (Syzygium cumini L.) terhadap struktur histologi trakea tikus putih (Rattus sp.) yang telah terpapar asap rokok.

\section{MATERI DAN METODE}

24 ekor tikus putih (Rattus sp) dengan berat badan 200250 gram digunakan dalam penelitian ini dan terdapat 4 perlakuan dengan 6 kali ulangan. Pada kelompok $\mathrm{K}_{0}$ diberi larutan CMC-Na 0,5\% (Carboxymethyl Cellulose Sodium). Kelompok $\mathrm{K}_{1}$ diberi perlakuan berupa paparan asap rokok. Kelompok $\mathrm{K}_{2}$ diberi ekstrak buah juwet sedangkan kelompok $\mathrm{K}_{3}$ diberi paparan asap rokok dan ekstrak buah juwet. Setiap satu hewan coba diberikan 1 batang rokok selama \pm 20 menit Rokok dinyalakan dengan bantuan aerator pump dan ektrak buah juwet diberikan sebanyak $2 \mathrm{ml}$ dengan dosis $360 \mathrm{mg} / 200 \mathrm{grBB}$. Ekstrak buah dan larutan $\mathrm{CMC} \mathrm{Na} 0,5 \%$ diberikan dengan menggunakan metode gevage selama 48 hari.

Hewan coba dikorbankan pada hari ke 49, trakea diambil kemudian dibersihkan dan difiksasi untuk dibuat sayatan histologi. Variable yang diamati adalah keberadaan silia, jumlah sel goblet, tinggi epitel, dan diameter lumen.

Keberadaan silia pada epitel trakea dianalisa secara diskriptif komperatif kemudian dibandingkan antara setiap perlakuan $\left(\mathrm{K}_{0}, \mathrm{~K}_{1}, \mathrm{~K}_{2}\right.$, dan $\left.\mathrm{K}_{3}\right)$. Jumlah sel goblet, tinggi epitel dan diameter lumen dianalisa dengan menggunakan analysis of variance (ANOVA), apabila terdapat perbedaan yang nyata $(\mathrm{P}<0,05)$ maka dilanjutkan dengan uji Duncan.

HASIL

1. Keberadaan Silia

Berdasarkan pengamatan secara deskriptif komperatif menggunakan mikroskop dengan perbesaran 400 kali menunjukkan bahwa paparan asap rokok menyebabkan 
Tabel 1. Keberadaan silia pada epitel pseudokomplek bersilia.

\begin{tabular}{|c|c|c|}
\hline Val & Ulangan & Skoring \\
\hline \multirow{6}{*}{$\begin{array}{c}\text { Kontrol } \\
\left(\mathbf{K}_{0}\right)\end{array}$} & 1 & +++ \\
\hline & 2 & +++ \\
\hline & 3 & ++ \\
\hline & 4 & ++ \\
\hline & 5 & +++ \\
\hline & 6 & +++ \\
\hline \multirow{6}{*}{$\begin{array}{c}\text { Rokok } \\
\left(K_{1}\right)\end{array}$} & 1 & + \\
\hline & 2 & + \\
\hline & 3 & + \\
\hline & 4 & - \\
\hline & 5 & ++ \\
\hline & 6 & - \\
\hline \multirow{6}{*}{$\begin{array}{c}\text { Juwet } \\
\left(\mathbf{K}_{2}\right)\end{array}$} & 1 & ++ \\
\hline & 2 & ++ \\
\hline & 3 & +++ \\
\hline & 4 & +++ \\
\hline & 5 & +++ \\
\hline & 6 & ++ \\
\hline \multirow{6}{*}{$\begin{array}{c}\text { Rokok } \\
\text { dan juwet } \\
\left(\mathbf{K}_{3}\right)\end{array}$} & 1 & ++ \\
\hline & 2 & ++ \\
\hline & 3 & + \\
\hline & 4 & ++ \\
\hline & 5 & + \\
\hline & 6 & ++ \\
\hline
\end{tabular}

Keterangan :

(-) Tidak terdapat silia $(0-25 \%) \quad(++)$ Terdapat banyak silia $(51-75 \%)$

$(+)$ Terdapat sedikit silia (26-50\%) (+++) Terdapat sangat banyak silia (76-100\%)
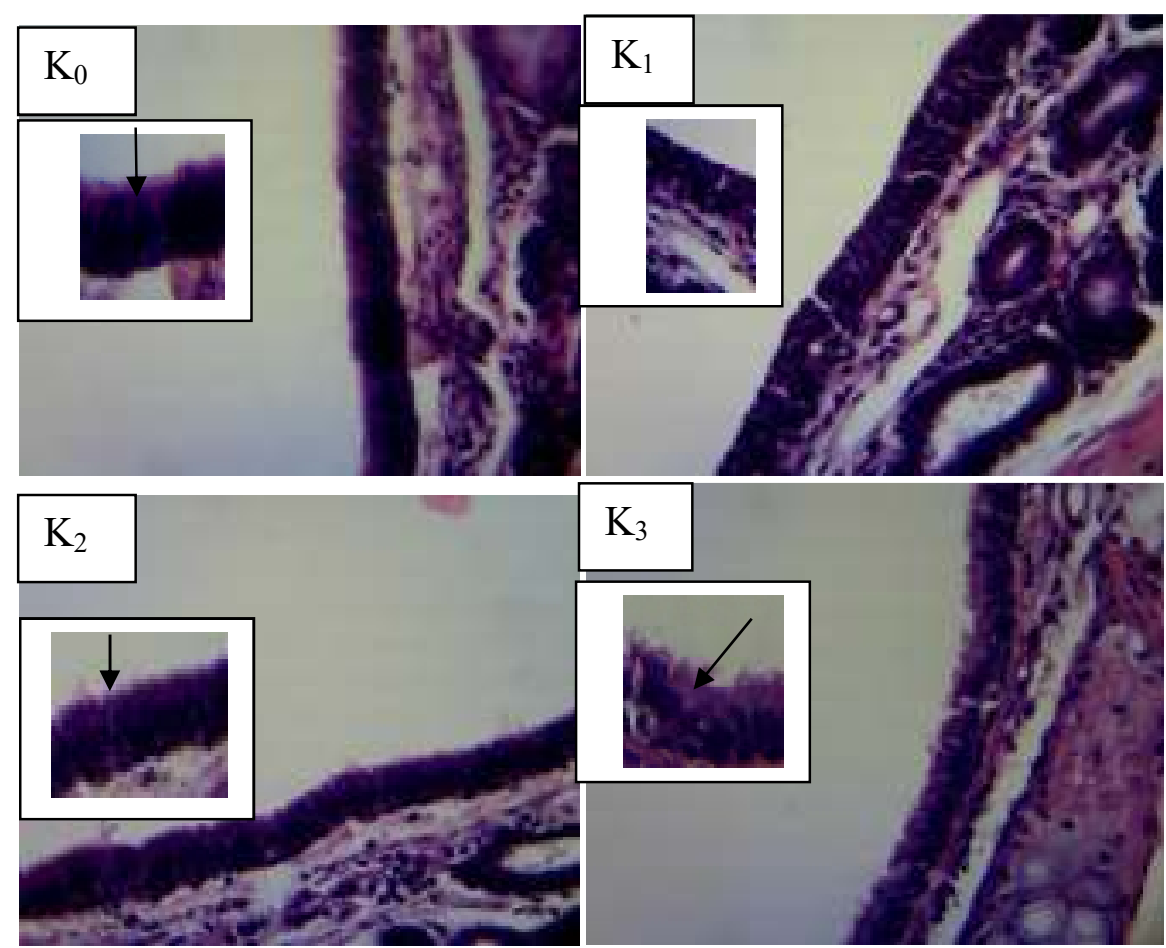

Gambar 2. Perbandingan keberadaan silia pada epitel pseudokomplek bersilia trakea tikus putih ke empat perlakuan

Tabel 2. Hasil rata-rata dan standar deviasi struktur histologi trakea tikus dewasa (Rattus sp) pada control dan perlakuan setelah diberi paparan asap rokok dan ekstrak juwet selama 48 hari.

\begin{tabular}{l|ccc}
\hline \multirow{2}{*}{ Perlakuan } & \multicolumn{3}{c}{ Variabel } \\
& Tinggi Epitel $(\mu \mathrm{m})$ & Sel Goblet(sel/mm) & Diameter lumen $(\mu \mathrm{m})$ \\
\hline Kontrol & $46,000 \pm 3,899^{\mathrm{a}}$ & $7,500 \pm 1,378^{\mathrm{a}}$ & $1737,167 \pm 192,750^{\mathrm{a}}$ \\
Rokok & $38,333 \pm 2,582^{\mathrm{b}}$ & $10,333 \pm 1,633^{\mathrm{b}}$ & $964,333 \pm 274,791^{\mathrm{b}}$ \\
& & & \\
Juwet & $43,833 \pm 2,483^{\mathrm{ac}}$ & $8,000 \pm 1,789^{\mathrm{ac}}$ & $1545,833 \pm 107,736^{\mathrm{ac}}$ \\
Rokok dan Juwet & $40,667 \pm 1,633^{\mathrm{bc}}$ & $8,668 \pm 1,967^{\mathrm{ab}}$ & $1168,500 \pm 93,117^{\mathrm{bc}}$
\end{tabular}




\section{Tinggi Epitel}

Hasil pengamatan menunjukan bahwa ekstrak buah juwet mampu mempertahankan tinggi epitel trakea dari paparan asap rokok dapat dilihat pada gambar 3 dan gambar 4 .

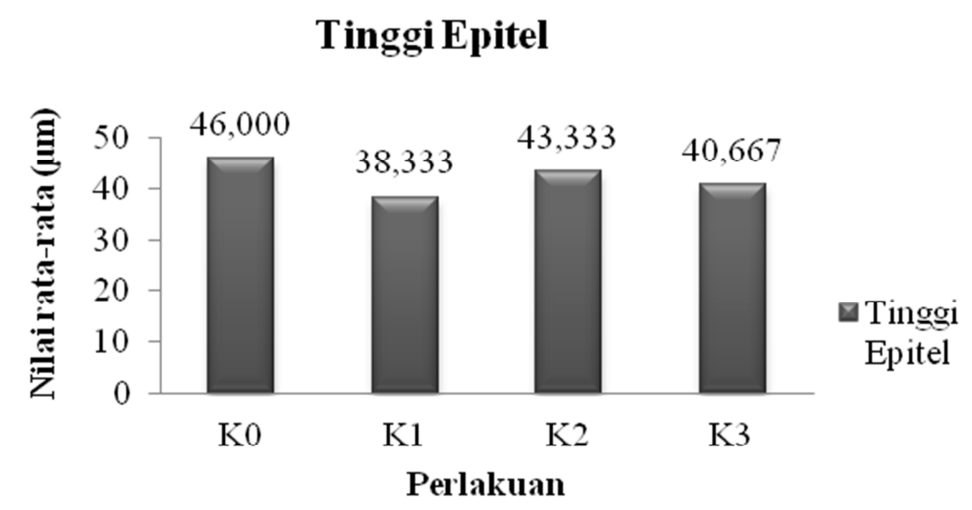

Gambar 3. Hasil rata-rata tinggi epitel pada trakea tikus putih (Rattus sp.) pada kontroldan perlakuan setelah diberikan paparan asap rokok dan pemberian ekstrakjuwet (S.cumini L.)

\section{Jumlah Sel Goblet}

Hasil pengamatan menunjukan bahwa ekstrak buah juwet mampu mempertahankan jumlah sel goblet dari paparan asap rokok dapat dilihat pada gambar 5 dan 6

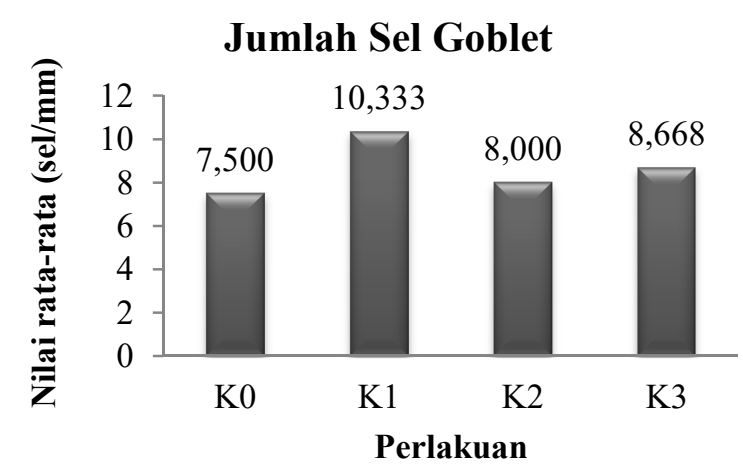

Gambar 5. Hasil rata-rata jumlah sel goblet pada trakea tikus putih (Rattus sp.) kelompok kontrol dan perlakuan setelah diberikan paparan asap rokok dan ekstrak buah juwet (S. cumini L.).

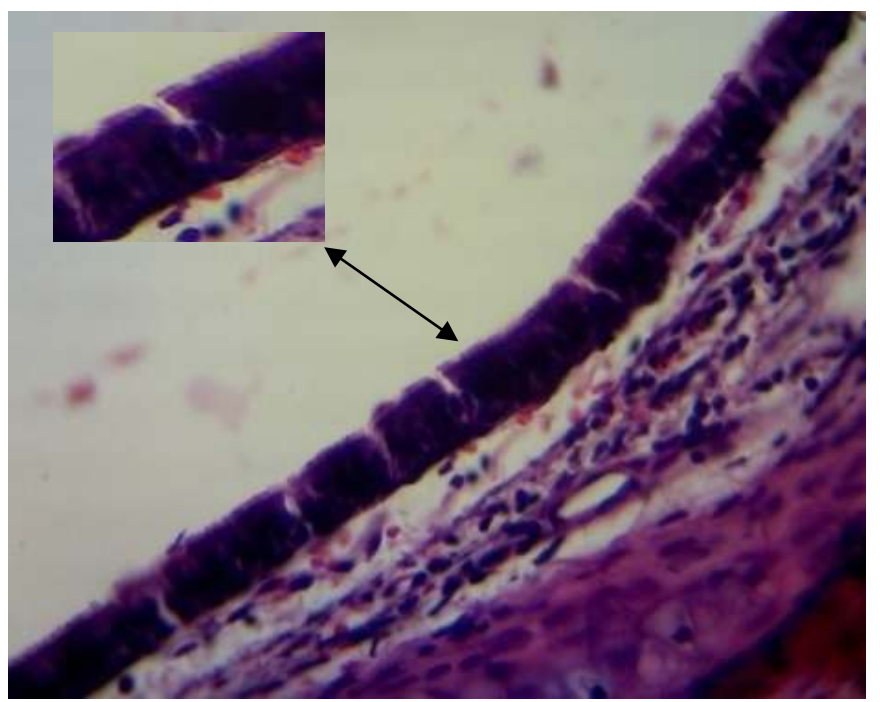

Gambar 6. Sel goblet pada epitel pseudokomplek silia ditunjuk dengan tanda panah.

\section{PEMBAHASAN}

Paparan asap rokok menyebabkan kerusakan yang terjadi pada struktur histologi trakea seperti mereduksinya silia yang terdapat pada epitel pseudokomplek bersilia, terjadinya hiperplasia sel goblet, memendeknya tinggi epitel, penyempitan diameter lumen trakea.
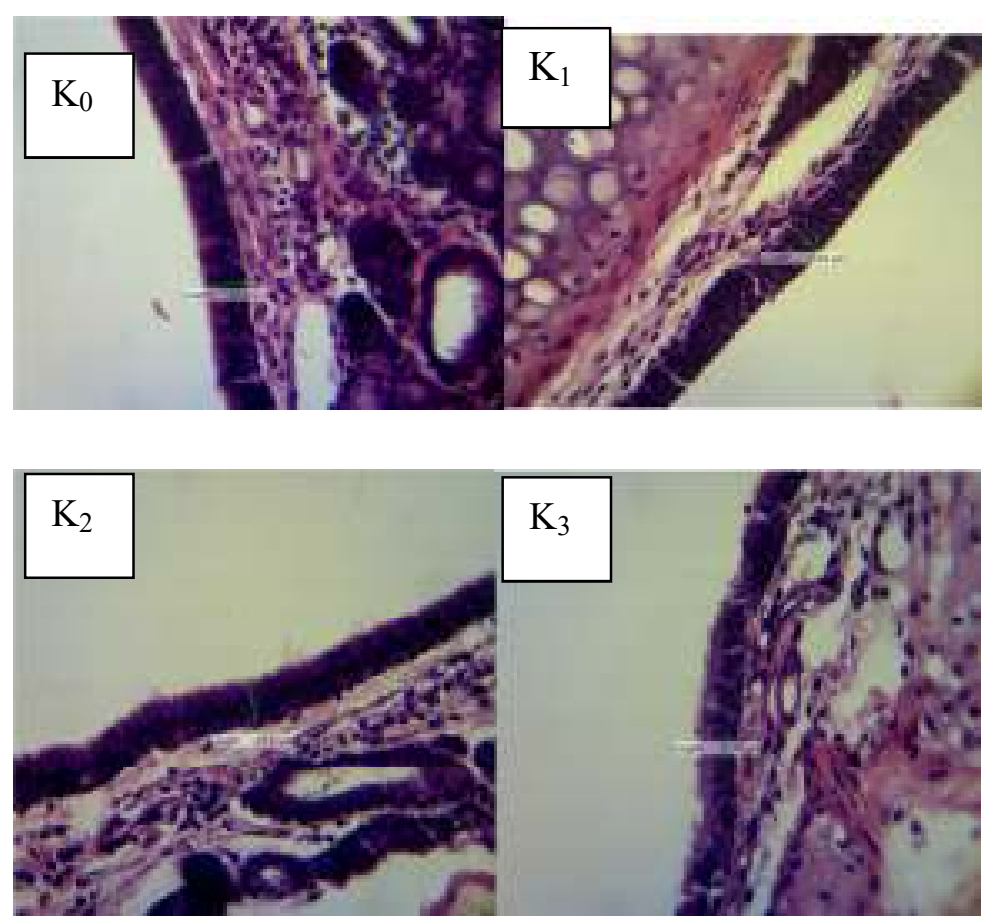

Gambar 4. Perbandingan tinggi epitel pseudokomplek bersilia trakea tikus putih ke empat perlakuan

\section{Diameter Lumen}

Hasil pengamatan menunjukan bahwa Ekstrak buah juwet mampu mempertahankan diameter trakea dari paparan asap rokok dapat dilihat pada Gambar 7 dan Gambar 8

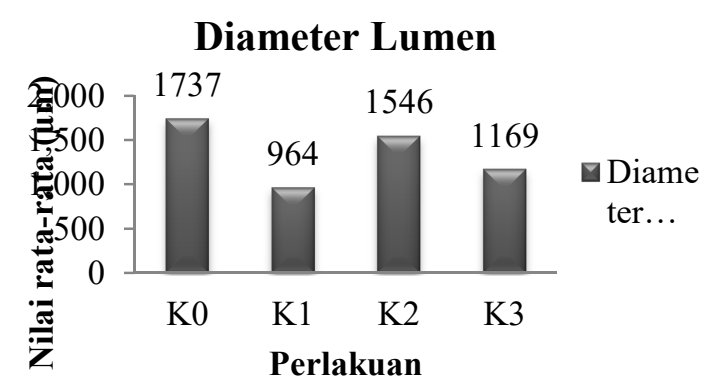

Gambar 7. Hasil rata-rata diameter lumen pada trakea tikus putih (Rattus sp.) kelompok kontrol dan perlakuan setelah diberikan paparan asap rokok dan ekstrak buah juwet (S. cumini L.)
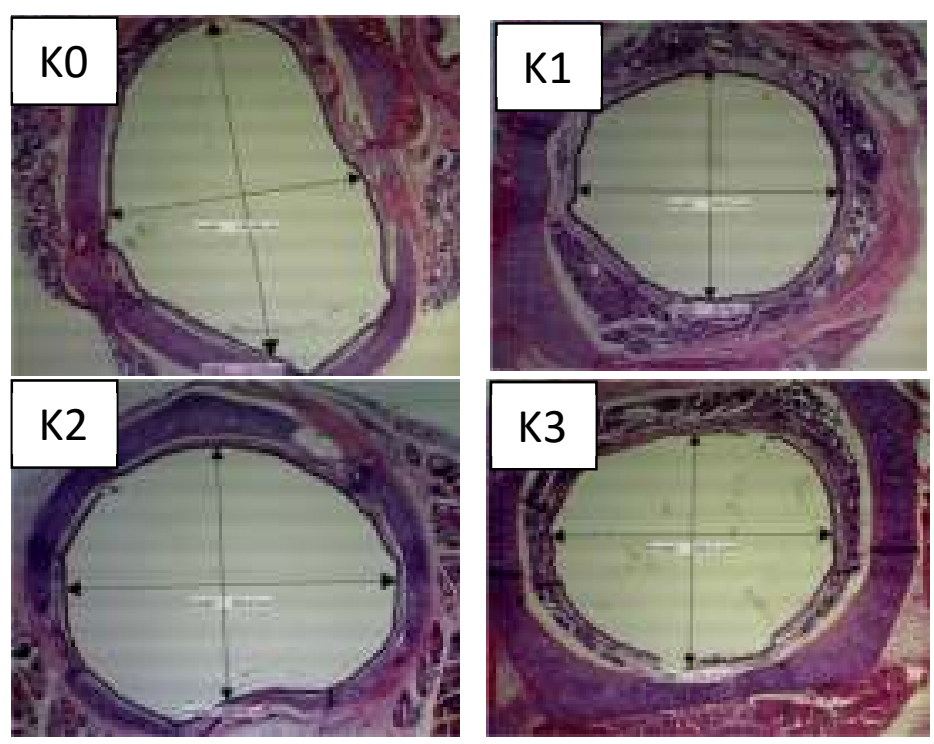

Gambar 8. Perbandingan diameter lumen trakea tikus putih ke empat perlakuan

Perlakuan yang diberi ekstrak buah juwet tidak berbeda nyata dengan kontrol karena buah juwet tidak bersifat toksik terhadap sel-sel trakea. Pada penelitian ini, paparan asap rokok menyebabkan penurunan keberadaan silia di permukaan epitel pseudokomplek bersilia pada trakea. Hal ini diduga karena adanya partikel debu yang masuk dan menempel pada silia 
akibat paparan asap rokok. Selanjutnya makrofag akan memfagosit partikel yang menempel pada silia tersebut. Partikel yang terkandung dalam asap rokok menempel pada silia dan akan merusak struktur dari silia, silia yang telah mengalami kerusakan akibat paparan asap rokok selanjutnya akan di fagosit oleh makrofag (Anindyajati, 2007). Paparan asap rokok memiliki dampak yang negatif dan sangat berbahaya bagi kesehatan tubuh seperti terjadinya stres oksidatif. Stres oksidatif tersebut disebabkan karena adanya peningkatan radikal bebas di dalam tubuh. Silia pada epitel pseudokomplek kelompok perlakuan paparan asap rokok dan ekstrak buah juwet jumlahnya lebih banyak dibandingkan dengan kelompok yang diberi paparan asap rokok saja. Hal ini karena pada buah juwet terdapat senyawa-senyawa aktif seperti flavonoid yang merupakan turunan dari antioksidan (Jagetia dkk,2005).

Antioksidan merupakan senyawa yang dapat menangkal radikal bebas dan memiliki peranan penting bagi kesehatan tubuh. Antioksidan diduga dapat melindungi sel dari radikal bebas dengan mengubah ion superoksida $\left(\mathrm{O}_{2}{ }^{*}\right)$ yang berasal dari lingkungan menjadi hidrogen peroksida $\left(\mathrm{H}_{2} \mathrm{O}_{2}\right)$ yang dibantu oleh enzim peroksida dismutase (SOD) dengan penambahan ion hidrogen. Hidrogen peroksida kemudian diuraikan menjadi air dengan bantuan enzim katalase (Hayati, 2011). Enzim katalase mampu menggunakan satu molekul $\mathrm{H}_{2} \mathrm{O}_{2}$ sebagai substrat elektron donor dan satu substrat akseptor sehingga 2 molekul $\mathrm{H}_{2} \mathrm{O}_{2}$ menjadi $2 \mathrm{H}_{2} \mathrm{O}$ dan $\mathrm{O}_{2}$. Jika molekul $\mathrm{H}_{2} \mathrm{O}_{2}$ tidak dikonversi menjadi $\mathrm{H}_{2} \mathrm{O}$ maka dapat membentuk radikal hidroksil $\left(\mathrm{OH}^{*}\right)$ yang bersifat reaktif. Radikal hidroksil $\left(\mathrm{OH}^{*}\right)$ akan semakin bersifat reaktif jika bereaksi dengan logam transisi $\left(\mathrm{Fe}^{+}\right.$atau $\left.\mathrm{Cu}^{+}\right)$, dan dapat menyebabkan terjadinya kerusakan pada sel khususnya pada membran sel melalui reaksi peroksidasi lipid, oksidasi protein dan oksidasi DNA (Werdhasari, 2014).

Tereduksinya silia pada epitel pseudokomplek bersilia menyebabkan pemendekan epitel trakea. Pemendekan epitel trakea diamati secara mikroskopis dan mendapatkan rata-rata dari setiap perlakuan yang berbeda-beda. Setelah dianalisa dengan uji One Way ANOVA menunjukkan hasil yang berbeda nyata $(\mathrm{P}<0,05)$ antara kelompok kontrol dengan perlakuan yang diberi paparan asap rokok dan perlakuan paparan asap rokok serta ekstrak buah juwet, sedangkan pada pemberian ekstrak buah juwet tidak menunjukkan hasil yang berbeda nyata dengan kelompok kontrol $(\mathrm{P}>0,05)$.

Pada kelompok kontrol $\mathrm{K}_{0}$ dan kelompok $\mathrm{K}_{2}$ memiliki nilai rata-rata tinggi epitel trakea lebih tinggi dibandingkan dengan kelompok yang diberikan paparan asap rokok. Hal ini disebabkan karena kandungan antioksidan pada buah juwet sangat penting terhadap tubuh yang mengalami stres oksidatif dan mampu melindungi sel-sel dari serangan radikal bebas dengan cara mendonorkan salah satu elektronnya kepada senyawa yang bersifat oksidan sehingga aktifitas senyawa oksidan tersebut dapat dihambat (Saleh dkk, 2012).

Perlakuan asap rokok menyebabkan berkurangnya tinggi epitel dan berbeda nyata dibandingkan dengan kontrol. Pemberian ekstrak juwet bersama-sama dengan paparan asap rokok memiliki nilai rata-rata lebih tinggi dibandingkan dengan yang hanya diberikan paparan asap rokok. Hal ini diduga ekstrak buah juwet mampu mengurangi serangan radikal bebas yang disebabkan oleh paparan asap rokok. Kelompok yang diberikan paparan asap rokok mengalami pemendekan pada epitel. Epitel trakea yang memendek ini disebabkan karena hilangnya silia pada permukaan epitel akibat pengaruh dari pemaparan asap rokok. Pemaparan yang terjadi secara terusmenerus dapat menyebabkan terjadinya ketidakseimbangan antara antioksidan dan radikal bebas di dalam tubuh sehingga menyebabkan terjadinya stres oksidatif. Peningkatan jumlah radikal bebas di dalam tubuh dapat menyebabkan peroksidasi lipid pada makromolekul di dalam sel epitel trakea. Kerusakan makromolekul yang disebabkan oleh radikal bebas paling rentan dialami oleh asam lemak tidak jenuh pada membran sel yang akan berdampak pada rata-rata tinggi epitel trakea (Sartono dan Nurmasari, 2005).

Peningkatan jumlah sel goblet pada kelompok yang diberikan paparan asap rokok. Hasil uji statistik dengan menggunakan One Way ANOVA menunjukkan hasil yang berbeda nyata $(\mathrm{P}<0,05)$ antara kontrol dan paparan asap rokok. Paparan asap rokok dapat menyebabkan peningkatan kadar ROS (Reactive Oxygen Species) sehingga menimbulkan perubahan pada struktur histologis trakea berupa peningkatan jumlah sel goblet. Paparan asap rokok yang diberikan secara berulang kali diduga dapat menyebabkan peningkatan indeks mitosis pada epitel saluran pernapasan hewan coba dan kemudian akan menyebabkan terjadinya hiperplasia sel goblet sehingga terjadi peningkatan sekresi mukus (Arkeman dan David, 2006). Kelompok yang diberikan ekstrak buah juwet memiliki jumlah sel goblet yang tidak berbeda nyata dengan kelompok kontrol. Hal ini disebabkan karena buah juwet mengandung senyawa antioksidan yang mampu menangkal radikal bebas sehingga struktur sel pada trakea tidak mengalami kerusakan dan tidak mengalami hiperplasia pada sel goblet (Arnentis dkk, 2010).

Rata-rata jumlah sel goblet pada kelompok $\mathrm{K}_{3}$ lebih banyak dibandingkan dengan kelompok $\mathrm{K}_{0}$ dan $\mathrm{K}_{2}$, tetapi lebih sedikit dibandingkan dengan kelompok $\mathrm{K}_{1}$. Hal ini diduga karena pemberian ekstrak buah juwet yang mengandung antioksidan mampu menangkal radikal bebas dan menghambat peningkatan kadar ROS (Reactive Oxygen Species) dengan cara mendonasikan sebuah elektron pada radikal bebas, radikal bebas menjadi bermuatan positif dan mengakhiri rangkaian reaksi oksidasi ke dalam bentuk yang lebih stabil. (Arkeman dan David, 2006).

Nilai rata-rata diameter lumen trakea yang paling rendah terlihat pada kelompok $\mathrm{K}_{1}$. Setelah diuji dengan menggunakan One Way ANOVA menujukkan hasil yang berbeda nyata $(\mathrm{P}<0,05)$ antara perlakuan. Hal ini diduga karena terjadinya penebalan tunika mukosa yang disebabkan adanya proses peradangan pada jaringan penyokong. Penebalan ini terjadi karena kandungan gas dan partikel yang terdapat asap rokok dapat menyebabkan bertambahnya jumlah cairan dalam tunika mukosa yang ditandai dengan adanya pembesaran ruang pada jaringan penyokong (Lesson dkk,1996) $\mathrm{K}_{3}$ memiliki diameter lumen lebih besar dibandingkan $\mathrm{K}_{1}$, hal ini diduga karena kelompok $\mathrm{K}_{3}$ diberikan perlakuan tembahan berupa ekstrak buah juwet. Kandungan senyawa kimia pada buah juwet seperti flavonoid mampu melindungi sel dari serangaan radikal bebas yang disebabkan oleh pemberian paparan asap rokok, sehingga kadar ROS didalam tubuh dapat berkurang dan mampu melindungi rawan hialin trakea dari kerusakan akibat paparan asap rokok (Maslachah dkk, 2008).

\section{KESIMPULAN}

Berdasarkan hasil penelitian dapat disimpulkan bahwa ekstrak buah juwet (Syzygium cumini L.) mampu mempertahankan struktur histologi trakea tikus putih (Rattus sp) yang telah terpapar asap rokok, yang terlihat dengan keberadaan silia pada epitel pseudokomplek bersilia, tidak terjadinya hiperplasia sel goblet, tidak terjadinya pemendekan pada epitel dan penyempitan pada diameter lumen trakea. 


\section{UCAPAN TERIMAKASSIH}

Terimakasih Kami ucapkan kepada Bapak Sang Ketut Sudirga dan Ibu I Gusti Ayu Manik Ermayanti Atas saran dan penulisan artikel ini.

\section{DAFTAR PUSTAKA}

Anindyajati, E. A. 2007. Pengaruh Asap Pelelehan Lilin Batik (Malam) Terhadap Struktur Histology Trakea Dan Alveoli Pulmo, Jumlah Eritrosit Serta Kadar Hemoglobin Mencit (Mus musculusL.). Skripsi. Jurusan Biologi. FMIPA UNS. Surakarta.

Arifin, H., Nelvi, A., Rasyid, R. 2006. Standarisasi Ekstrak Etanol Daun Eugenia Cumini Merr. Jurusan Farmasi Fakultas MIPA Universitas Andalas. $J$ sains tek. Far. 11(2). 88-93

Arkeman, H.,David. 2006. Efek Vitamin C Dan E Terhadap Sel Goblet Saluran Nafas Pada Tikus Akibat Pajanan Asap Rokok. Bagian Histologi Fakultas Kedokteran Universitas Trisakti. Universal Medicina. 25 (2). 61-66

Arnentis., Yustina., Purwandari, C. 2010. Daya Proteksi Vitamin C Terhadap Radikal Bebas Yang Disebabkan Oleh Asap Rokok Terhadap Sel Goblet Pada Trakea Mencit. Pendidikan Biologi FKIP Universitas Riau. ISBN.978-1222-93-8 (jilid 2).

Fajri. H. R., Raden, A., Choesnan, E. 2015. Pengaruh Pemberian Glutathione Pra Latihan Submaksimal Terhadap Jumlah Trombosit Dan Masa Perdarahan : Studi Eksperimental Pada Hewan Coba. Pendidikan Dokter Fakultas, Universitas Airlangga, Surabaya. Sport and Fitnes Journal. 3(1). 52-58

Hayati, A. 2011. Spermatologi. Airlangga University press (ALIP). Surabaya.

Jagetia, G.C., Baliga, M.S., Venkatesh, P. 2005. Influence Of Seed Extract Of Syzygium Cumini (Jamun) On Mice Exposed To Different Doses Of $\gamma$ Radiation. Departemen of Radiobiologi, Kasturba Medical College, Manipal (India). $J$ Radiat Res. 1 (46). 59-65

Lesson, S.T., Lesson, C.R., Paparo, A.A. 1996. ED-5. Buku ajar histology. Jakarta. EGC

Maslachah, L., Rahmi, S., Rahma, K. 2008. Hambatan Produksi Reactive Species Radikalsuperoksida $\left(\mathrm{O}_{2}{ }^{-}\right)$Oleh Antioksidan Vitamin E $(\alpha-$ tocopherol) Pada Tikus Putih (Rattus norvegicus) yang Menerima Stressor Renjatan Listrik. Pharmacology veteriner Departemen Ilmu Kedokteran Dasar, Fakultas Kedokteran Hewan, Universitas Airlangga. Media Kedokteran Hewan. 24(1). 21-26

Muchtadi, D., 2013. Pangan dan Kesehatan Jantung. Alfabeta. Bandung.

Saleh, L. P., Edi, S., Adithya, Y. 2012. Aktivitas Antioksidan Dari Ekstrak Tongkol Jagung (Zea mays L.). Jurnal MIPA UNSRAT Online. Manado.3(2).2024

Samantha, M. S., Joseph, H. S., Jacqueline, A. P., Jane, M. D., Craig, B., Xiangde, L., Kawasaki, S., Jhon, G.S., Stephen, I.R., Todd, A.W. 2010. Long - Term Cigarette Smoke Exposure In A Mouse Model Of Ciliated Epithelial Cell Function. Am $J$ Respir Cell Mol Bio. 6 (43). 635-640

Sartono dan Nurmasari. 2005. Pengaruh Pajanan Asap Rokok Kretek Secara Pasif Terhadap Epitel Bronkiulus Dan Kandungan GSH Paru Tikus Galur Swiss Webster. Tesis. Perpustakaan Universitas Indonesia.
Susanna, D., Budi, H., Hendra, F. 2003. Penentuan Kadar Nikotin Dalam Asap Rokok. Depertamen Kesehatan Lingkungan, Fakultas Kesehatan Masyarakat, Universitas Indonesia. Depok. Makara, Kesehatan. 7(2). 39-41

Sukmaningsih. A.A.Sg.A., N.M. Rai. S., N.W. Sudatri., T. Pangestiningsih., S. Widyarini. 2015. Apoptosis Sel Spermatogenik Pada Tikus Putih (Rattus Norvegicus) Yang Terpapar Asap Rokok Setelah Pemberian Ekstrak Buah Juwet (Syzygium cumini). Seminar Nasional Sains dan Teknologi. Kuta, tanggal 29-30 Oktober.

Werdhasari, A., 2014. Peran Antioksidan Bagi Kesehatan. Pusat Biomedis dan Teknologi Dasar Kesehatan Balitbangkes. Jurnal Biiotek Medisiana Indonesia. 2(3). 59-68 